\title{
Analisis Tegangan pada Kapal Perang Tipe Corvette Akibat Beban Slamming
}

\author{
Sugiyarto, Aries Sulisetyono, Teguh Putranto \\ Jurusan Teknik Perkapalan, Fakultas Teknologi Kelautan, Institut Teknologi Sepuluh Nopember (ITS) \\ Jl. Arief Rahman Hakim, Surabaya 60111 Indonesia \\ e-mail: sulisea@na.its.ac.id, theories@na.its.ac.id
}

\begin{abstract}
Abstrak - Kapal perang biasanya desain untuk dapat melaju pada kecepatan tinggi dan harus memiliki manouver yang bagus. Namun pada kenyataannya, pada waktu beroperasi, kapal perang dihadapkan pada kondisi lingkungan yang tidak menentu yang menyebabkan terjadinya slamming. Slamming disini menyebabkan terjadinya kegagalan struktur pada kapal sehingga membahayakan keselamatan. Tugas akhir ini menganalisa tegangan pada kapal perang tipe Corvette akibat beban slamming. Beban slamming yang terjadi akibat variasi tinggi gelombang 4, 5, dan 6 serta variasi sudut hadap 90 derajat, 135 derajat dan 180 derajat. Dari analisa yang didapatkan bahwa semakin tinggi beban gelombang maka semakin tinggi peluang terjadinya slamming, intensitas terjadi slamming, beban slamming dan tegangan yang diakibatkan beban slamming. Kondisi paling ekstrim terjadinya slamming terjadi pada sudut 180 derajat pada tinggi gelombang 6 meter dengan nilai probabilitas terjadinya slamming mencapai 0.71 serta jumlah kejadian slamming per jam mencapai 527 kali kejadian. Beban terbesar akibat slamming mencapai $92,619 \mathrm{kPa}$ pada bagian 0.15 dari FP. Tegangan yang terjadi masih memenuhi standart aturan BKI.
\end{abstract}

Kata kunci: Slamming, Kapal Corvette, Sudut hadap, Tinggi gelombang, Tegangan

\section{PENDAHULUAN}

$\mathrm{K}$ APAL perang merupakan salah satu alutsista setiap negara yang dipersiapkan utamanya untuk pertahanan, kapal perang dilengkapi dengan senjata, dari mulai senjata kecil, besar, hingga peluru kendali dan radar serta berbagai kecanggihan lainnya seiring perkembangan zaman, bahkan beberapa kapal perang memiliki atau membawa sebuah senjata rudal berhulu ledak nuklir, selain itu kapal perang juga ada yang ditenagai oleh nuklir untuk penggerak mesinnya, bahkan untuk kapal selam bertenaga nuklir dapat bertahan bertahun-tahun dibawah permukaan air tanpa harus naik kepermukaan selama kebutuhan awaknya masih tercukupi. Kapal perang sendiri sudah banyak yang memiliki kecanggihan "stealth" atau bisa tidak terdeteksi oleh radar. Kapal perang biasanya desain untuk dapat melaju pada kecepatan tinggi dan harus memiliki stabilitas yang bagus. Namun pada kenyataannya, pada waktu beroperasi, kapal perang dihadapkan pada kondisi lingkungan yang tidak menentu yang menyebabkan terjadinya slamming serta greenwater [1].

Slamming adalah fenomena yang terjadi apabila dasar haluan naik melewati permukaan gelombang dan kemudian masuk kembali ke dalam air dengan kecepatan relatif vertikal haluan mempunyai harga yang melewati harga tertentu dan timbul hempasan [1]. Slamming terjadi karena terdapat beda fase struktur kapal dengan fase gelombang. Perbedaan fase ini menyebabkan struktur kapal dapat terangkat keluar dari permukaan laut dan setelah itu jatuh menghantam permukaan laut tersebut. Kejadian masuknya lambung kapal ke dalam permukaan laut ini terjadi begitu cepat hingga menghasilkan beban impact yang disebut beban slamming.

Beban slamming didapatkan dari analisa respon spektrum gelombang. Beban inilah yang dialami pada bagian kapal. Beban inilah yang dapat menyebabkan timbulnya tegangan pada struktur kapal, dan dapat mengakibatkan kerusakan pada struktur kapal. Untuk mengantisipasi hal tersebut sehingga dalam proses desain dilakukan proses perhitungan untuk analisa tegangan yang diakibatkan terjadinya beban slamming. Dimana kapal Corvette masih dalam proses desain. Sehingga mengantisipasi terjadinya kerusakan pada kapal dilakukan proses analisa tegangan akibat beban slamming. Analisa yang dihasilkan dalam perhitungan dibandingkan dengan rule sehingga didapatkan desain yang sesuai dengan aturan rule.

\section{DASAR TEORI}

\section{A. Dinamika Kapal}

Seakeping adalah gerakan kapal yang dipengaruhi oleh gaya-gaya luar yang disebabkan oleh kondisi air laut. Setiap kapal memiliki karakteristik gerakan berbeda ketika memperoleh gaya dari gelombang, bergantung pada faktor bentuk lambung, letak titik berat dan faktor lainnya. Gerakan kapal sendiri dibagi menjadi 6 macam berdasarkan sumbu geraknya diilustrasikan sesuai Gambar 1, yakni surge, sway, heave, roll, pitch, and yaw [2].

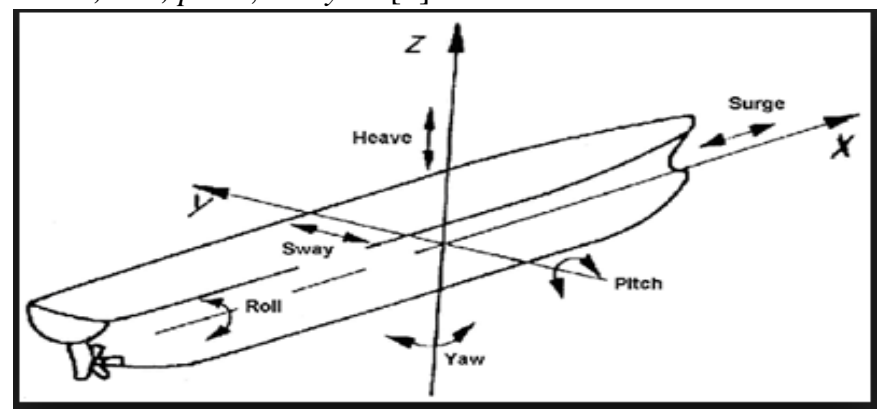

Gambar 1. Gerakan 6 derajat kebebasan kapal (Sumber: Helmidang.com)

\section{B. Gerakan Coupled Heave dan pitch}

Menurut Bhatacharyya (1978) [3] persaman untuk gerak coupled heave - pitch motion pada kapal dituliskan dalam persamaan:

Heave: 
$(m+a z) \ddot{z}+b \ddot{z}+c z+d \theta+e \theta+h \theta=(t)$

Pitch:

$(I y y+A y y) \theta+B \theta+C \theta+D \ddot{z}+E \dot{z}+H z=(t)$

Setelah menghitung komponen-komponen hidrodinamis di atas, maka didapatkan persamaaan heaving dan pitching sebagai berikut:

Heave:
$\mathrm{z}=\mathrm{za} \cos (\omega \mathrm{et}+\varepsilon \mathrm{z})$

Pitch:

$\theta=\theta \mathrm{a} \cos (\omega \mathrm{et}+\varepsilon \theta)$

\section{Vertical Motion}

Gerakan vertikal pada sepanjang kapal akan berbeda-beda. Hal ini terjadi karena terjadinya gerakan heave dan pitch bersamaan. Gerakan ini dinamakan coupled heaving and pitching motion. Menurut Bhattacharyya [3] gerakan dirumuskan sebagai berikut:

$$
\mathrm{zb}=\mathrm{z}+\xi \sin \theta
$$

dimana:

$$
\begin{array}{ll}
z b & =\text { vertical motion } \\
z & =\text { heaving motion } \\
\xi & =\text { jarak section terhadap CG } \\
\theta & =\text { pitching motion }
\end{array}
$$
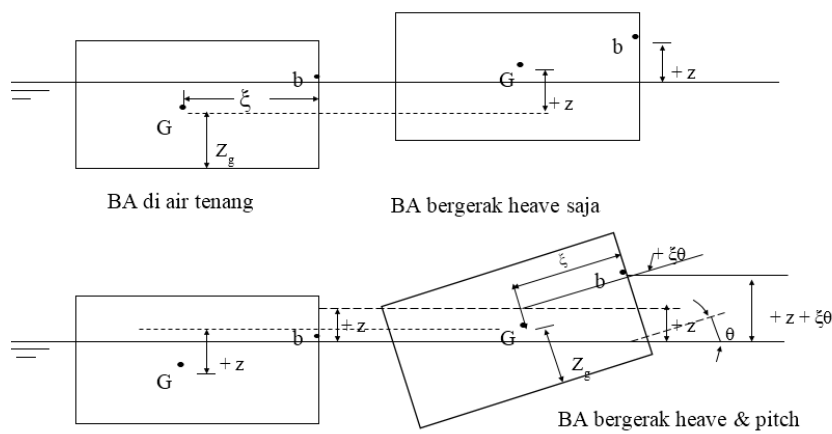

Gambar 2. Gerakan couple heaving pitching

\section{Wave Spectrum}

Dalam analisa pada gelombang irreguler terdapat perbedaan tinggi gelombang, dan frekuensi gelombang. Sehingga perlu dilakukan analisa pendekatan numerik Salah satunya yaitu formulasi ITTC. Formulasi tersebut memberikan persamaan spectrum energy gelombang sebagai fungsi tinggi gelombang signifikan, H1/3 dan frekuensi karakteristik:

$$
\mathrm{S}\left(\omega_{\mathrm{e}}\right)=\left(\frac{\mathrm{A}}{\omega_{e}}\right] e^{\frac{-B}{w_{w^{4}}}}
$$

dimana:

$$
\begin{array}{ll}
\omega_{\omega} & : \text { Frekuensi gelombang }(\mathrm{rad} / \mathrm{sec}) \\
\mathrm{A} & : 8.10 \times 10^{-3} \mathrm{~g}^{2} \\
\mathrm{~B} & : 3.11 \times 10^{4} /(\mathrm{H})^{2}{ }_{1 / 3} \\
(\mathrm{H})_{1 / 3} & : \text { Significant wave height }(\mathrm{m})
\end{array}
$$

\section{E. Probabilitas Slamming}

Menentukan peluang terjadinya Slaming harus didasarkan 2 syarat. Pertama yaitu dasar haluan naik melewati (emerge) gelombang, atau dengan kata lain gerakan relatif vertikal haluan melampaui sarat air bagian haluan $(\mathrm{zb}>\mathrm{Tb})$, dan kecepatan relatif vertikal haluan mempunyai harga yang melewati harga kecepatan ambang batas slamming atau threshold velocity [3]. Atau secara matematis dituliskan:

$\operatorname{Pr}($ slam $)=\operatorname{Pr}\left(Z_{b r}>T_{b} d a n V_{b r}>V_{t h}\right)=\exp \left(-\frac{T_{b}^{2}}{2 m_{0 Z b r}}-\frac{V_{t h}^{2}}{2 m_{0 V b r}}\right)_{(7)}$

dimana:

$\mathrm{m}_{\mathrm{ozr}}$ dan $\mathrm{mo}_{\mathrm{vbr}}$ didapat dari perhitungan respon spectrum

\section{F. Intensitas Slamming}

Setelah didapatkan nilai probabilitas slamming selanjutnya menentukan nilai intensitas terjadinya slamming. Sehingga digunakan persamaan sebagai berikut:

$$
N_{\text {slam }}=\frac{1}{2 \pi} \sqrt{\frac{m_{2 Z \text { Zbr }}}{m_{0 Z \text { Zbr }}}} \times \operatorname{Pr}(\text { slam })
$$

\section{G.Beban Slamming}

Beban slamming pada kapal mempertimbangkan pengaruh bentuk lambung kapal, kecepatan dan percepatan gerakan vertikal haluan kapal. Sehingga diformulasikan dalam persamaan berikut [3]:

$\left.\mathrm{P}=\mathrm{P}_{0}\left[\frac{2}{\beta \sqrt{1-\left(\frac{Y s}{2 b}\right)^{2}}}+\frac{2}{\delta} \sqrt{\left(1-\frac{Y s}{2 b}\right.}\right)^{2}-\frac{(Y s / 2 b)^{2}}{1-\left(\frac{Y s}{2 b}\right)^{2}}\right]$

dimana Po $==\frac{1}{2} \rho\left(\dot{\mathrm{z}}_{x}\right)^{2}$ dan $\delta=\frac{\left(\dot{\mathrm{z}}_{x}\right)^{2}}{2 b \check{\mathrm{Z}}_{x}}$

\section{H. Shear Force dan Bending Moment}

Shear force adalah gaya yang dialami oleh suatu struktur sehingga menyebabkan gerakan translasi pada struktur tersebut.

$f(x)=\frac{d^{2} M}{d x^{2}}$

Bending moment disebabkan karena 2 hal yaitu pada air tenang (Ms), yang kedua adalah bending moment yang disebabkan oleh perbedaan distribusi displacement sepanjang kapal (Mw). Sehingga untuk menentukan bending moment total didapatkan dari persamaan sebagai berikut:

$$
\mathrm{M}=\mathrm{Ms}+\mathrm{Mw}
$$

Bending moment dapat menimbulkan tegangan pada konstruksi kapal yang dapat menyebabkan kerusakan pada konstruksi kapal. Kerusakan dapat timbul apabila tegangan yang dialami struktur kapal melebihi tegangan ambang batas ijin. Batasan tegangan yang diijinkan pada suatu kapal telah diatur didalam klasifikasi. 


\section{METODOLOGI}

\section{A. Data Kapal}

Kapal yang digunakan sebagai acuan dalam penelitian ini adalah kapal perang tipe Corvette dengan ukuran sebagai berikut pada Tabel 1:

Tabel 1.

Ukuran utama kapal [4]

\begin{tabular}{ccc}
\hline \hline Description & Quantity & Unit \\
\hline LOA & 106 & $\mathrm{~m}$ \\
LPP & 98.93 & $\mathrm{~m}$ \\
$\mathrm{H}$ & 8.75 & $\mathrm{~m}$ \\
$\mathrm{~T}$ & 3.7 & $\mathrm{M}$ \\
$\mathrm{Cb}$ & 0.496 & \\
$\mathrm{Cp}$ & 0.667 & Knots \\
Speed & 30 & \\
\hline \hline
\end{tabular}

Selain Data ukuran utama kapal Corvette data yang digunakan untuk analisa adalah gambar midship section, gambar construction profile, gambar longitudinal section

\section{B. Validasi Model}

Metode validasi yang digunakan yaitu dengan membandingkan data penelitian yang sudah pernah dilakukan dengan data hasil program Software dengan model dan parameter yang sama. Proses validasi ini mengacu referensi dari WAMIT-MOSES Hydrodynamic Analysis Comparison Study. Di dalam paper WAMIT-MOSES Hydrodynamic Analysis Comparison Study menggunakan beberapa model antara lain box, cylinder, general ship, TLP, dan semisumbersible [5].

\section{Pemodelan Kapal pada Software}

Pada tahap selanjutnya dilakukan pemodelan permodelan numeris pada software dengan parameter yang diperlukan antara lain kecepatan kapal, sudut datang gelombang dan koordinat COG. Tujuan dari permodelan ini adalah untuk mendapatkan model struktur yang sesuai dan selajutnya digunakan dalam analisa respon spektrum.

\section{Grid Independence}

Proses grid independence bertujuan untuk mengukur keakuratan hasil. Hasil yang ditampilkan pada Ansys Aqwa tergantung dari banyaknya jumlah elemen pada model. Semakin banyak jumlah elemen maka semakin akuran proses analisa yang mendekati keadaan sebenarnya. Namun dalam proses analisa tidak hanya berdasarkan keakuratan analisa tetapi juga mempertimbangkan waktu yang digunakan. Hasil yang digunakan dalam pertimbangan analisa ini berdasarkan pada besar bending momen. Pada penelitian sebelumnya telah dilakukan dimana selisih untuk nilai antara bending moment yang diijinkan sebesar 5\%. Hasil bending moment dan jumlah elemen disajikan pada Gambar 3.

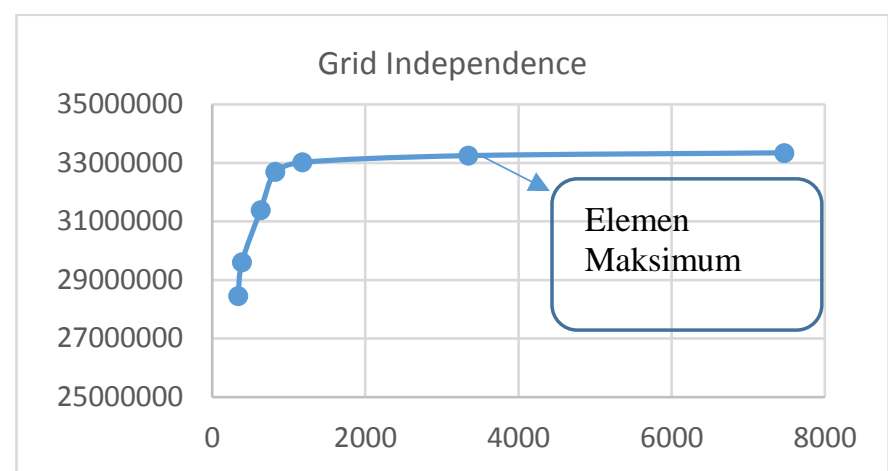

Gambar 3. Grid independent studying

1) Analisa Wave Spectrum

Setelah didapatkan hasil RAO dari Ansys Aqwa selanjutnya dilakukan analisa wave spectrum gelombang untuk mengetahui berapa besar beban gelombang yang sesungguhnya pada keadaan gelombang irregular. Analisis wave Spectrum merupakan cara unuk mendapakan gelombang irregular. Pada pengerjaan tugas akhir ini diambil wave spectrum dengan metode ITTC.

2) Perhitungan Slamming

Untuk menghitung slamming perlu dilakukan analisa perhitungan Relative Bow Motion (RBM). Sebelum menghitung RBM perlu dilakukan analisa respon spektrum di haluan kapal pada kondisi heaving dan pitching. Setelah didapatkan RBM dilakukan perhitungan untuk mendapatkan relative bow velocity. Dari hasil analisa tersebut dapat dilakukan proses perhitungan untuk menghitung peluang terjadinya slamming, intensitas slamming dan beban slamming.

3) Pemodelan di Poseidon

Pada tahap ini akan dilakukan proses pemodelan konstruksi kapal Corvette pada Poseidon. Proses pemodelan ini didasarkan pada ukuran dan tebat pelat pada konstruksi midship section, contruction profile, dan longitudinal section yang sudah ada. Proses pemodelan Pemodelan dalam aplikasi ini terdapat beberapa tahapan.

Tahapan-tahaan tersebut harus dilakukan secara benar, agar model dapat di-running (proses perhitungan yang dilakukan olah komputer). Beban yang digunakan pada pemodelan poseidon menggunakan beban shear force dan bending moment. Sehingga beban yang digunakan pada pemodelan ini yaitu input beban shear force bending moment akibat beban gelombang ditambah shear force bending momen akibat beban gelombang pada kondisi ekstrim [6].

\section{ANALISA DATA}

\section{A. Respon Spectrum RBM}

Perlu dilakukan perhitungan untuk mendapatkan spectra density of relative bow motion untuk mengetahui respon paling ekstrim pada bagian haluan kapal sehingga didapatkan grafik berikut: 


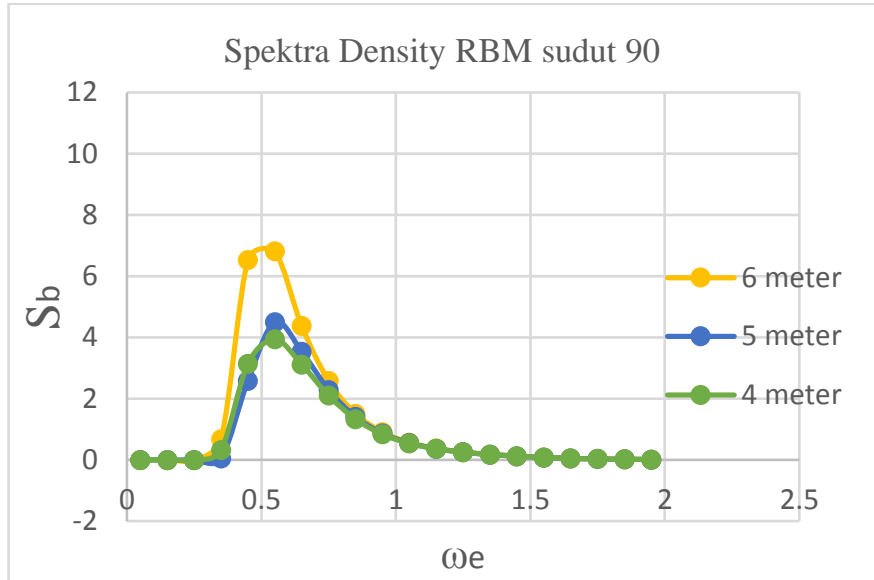

Gambar 4. Respon spektrum RBM sudut $90^{\circ}$

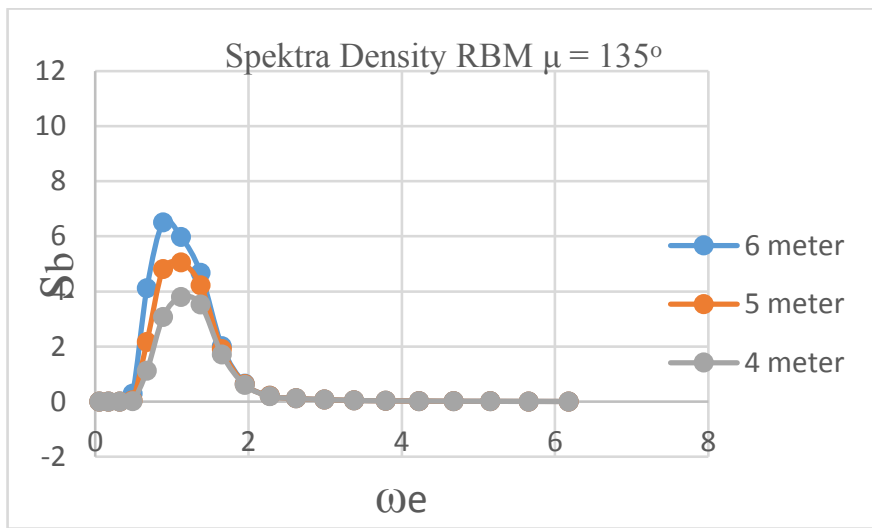

Gambar 5. Respon spektrum RBM sudut $135^{\circ}$

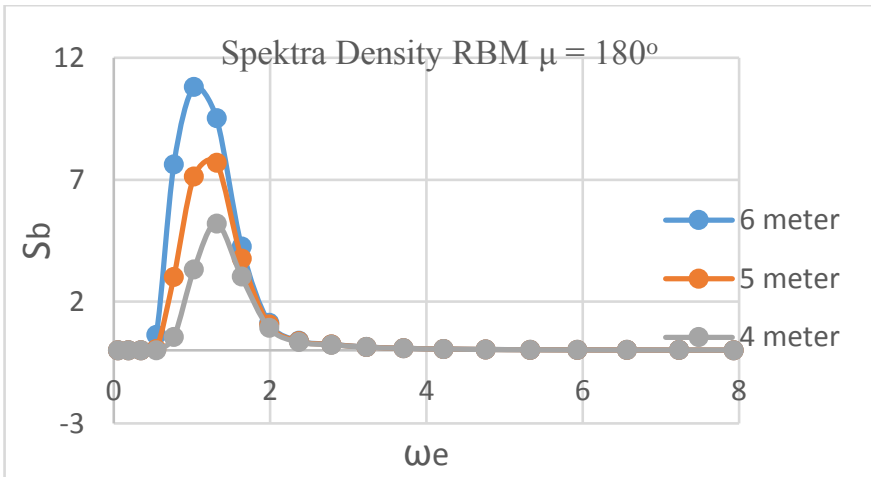

Gambar 6. Respon spektrum RBM sudut $180^{\circ}$

Dari Gambar 4, Gambar 5, dan Gambar 6 diatas menunjukan respon spectrum density RBM. Respon spectrum density $R B M$ terbesar pada tinggi gelombang 6 meter dengan sudut hadap $180^{\circ}$, sedangkan respon spectrum RBM terkecil pada sudut hadap $135^{\circ}$. Respon spectrum RBM terbesar pada frekuensi encounter $0,5-1,0 \mathrm{rad} / \mathrm{s}$.

\section{B. Probabilitas Slamming}

Setelah didapatkan hasil respon spektrum selanjutnya bisa dilakukan perhitungan probabilitas slamming. Probabilitas didapatkan dengan cara mencari luasan energi dari grafik spectra relative bow motion dan dari spectrum relative velocity. Perhitungan itu digunakan untuk mencari nilai $\mathrm{m}_{\mathrm{os}}$ dan $\mathrm{m}_{2 \mathrm{~s}}$. Tabel 2 menunjukan nilai probabilitas slamming yang dialami kapal.
Tabel 2.

Probabilitas slamming

\begin{tabular}{|c|c|c|c|c|c|c|c|c|c|}
\hline \multirow{2}{*}{$\begin{array}{c}\mathrm{Hs} \\
(\mathrm{m})\end{array}$} & \multicolumn{3}{|c|}{$\mathrm{m}_{\mathrm{os}}$} & \multicolumn{3}{c|}{$\mathrm{m}_{2 \mathrm{~s}}$} & \multicolumn{3}{c|}{$\mathrm{Pr}$} \\
\cline { 2 - 10 } & $90^{\circ}$ & $135^{\circ}$ & $180^{\circ}$ & $90^{\circ}$ & $135^{\circ}$ & $180^{\circ}$ & $90^{\circ}$ & $135^{\circ}$ & $180^{\circ}$ \\
\hline 4 & 2.67 & 8.12 & 11.03 & 1.66 & 14.10 & 25.76 & 0.01 & 0.33 & 0.47 \\
\hline 5 & 3.13 & 10.98 & 18.60 & 1.86 & 17.21 & 35.88 & 0.01 & 0.43 & 0.62 \\
\hline 6 & 4.30 & 13.89 & 26.71 & 2.22 & 19.83 & 44.87 & 0.03 & 0.50 & 0.71 \\
\hline
\end{tabular}

Dari Tabel 2 mempresentasikan perbedaan peluang terjadinya slamming terhadap variasi perbedaan sudut hadap datangnya gelombang dan variasi tinggi gelombang. Probabilitas slamming paling besar terjadi pada sudut $180^{\circ}$ dengan panjang gelombang 6 meter dengan nilai probabilitas sebesar 0.71. Pada tinggi gelombang 4-6 meter pada sudut $180^{\circ}$ probabilitas terjadinya slamming kisaran $0.467-0.71$. Pada sudut hadap $135^{\circ}$ memiliki kisaran probabilitas slamming sebesar 0.328 - 0.501 serta pada sudut hadap $90^{\circ}$ memiliki kisaran probabilitas sebesar 0.006 - 0.030. Variasi sudut hadap dan tinggi gelombang berpengaruh cukup signifikan terhadap peluang terjadinya slamming.

\section{Intensitas Slamming}

Selain probabilitas slamming juga didapatkan nilai jumlah kejadian slamming pada kapal Corvette. Jumlah kejadian slamming disajikan berdasarkan fungsi waktu. Sehingga didapatkan jumlah kejadian slamming dalam per detik, per jam dan per hari seperti tabel 3 dibawah.

$$
\text { Tabel } 3 .
$$

Intensitas slamming kapal corvette

\begin{tabular}{|c|c|c|c|c|c|c|c|c|c|}
\hline \multirow{2}{*}{$\mathrm{Hs}$} & \multicolumn{3}{|c|}{$\mathrm{Ns}($ perdetik ) } & \multicolumn{3}{c|}{ Ns( perjam ) } & \multicolumn{3}{c|}{$\mathrm{Ns}($ perhari ) } \\
\hline & $90^{\circ}$ & $135^{\circ}$ & $180^{\circ}$ & $90^{\circ}$ & $135^{\circ}$ & $180^{\circ}$ & $90^{\circ}$ & $135^{\circ}$ & $180^{\circ}$ \\
\hline 4 & 0.001 & 0.07 & 0.11 & 2.71 & 247.64 & 409.29 & 64.97 & 5943.41 & 9823.01 \\
\hline 5 & 0.001 & 0.09 & 0.14 & 5.05 & 306.67 & 496.08 & 121.14 & 7359.98 & 11905.80 \\
\hline 6 & 0.003 & 0.10 & 0.15 & 12.19 & 342.82 & 527.62 & 292.50 & 8227.71 & 12662.80 \\
\hline
\end{tabular}

Tabel 3 menunjukan bahwa jumlah kejadian Slamming paling besar terjadi pada gelombang dengan sudut hadap $180^{\circ}$ dengan tinggi gelombang 6 meter dengan nilai kejadian slamming per jam mencapai 528 kali kejadian. Untuk sudut hadap $135^{\circ}$ dengan tinggi gelombang 6 meter mencapai 342 kali kejadian per jam sedangkan untuk sudut hadap $90^{\circ}$ hanya terjadi 12 kali terjadi slamming.

1) Beban Slamming

Beban slamming dihasilkan karena adanya benturan antara permukaan air dengan badan kapal. Beban slamming dipengaruhi oleh kecepatan relatif dan percepatan vertikal haluan kapal.

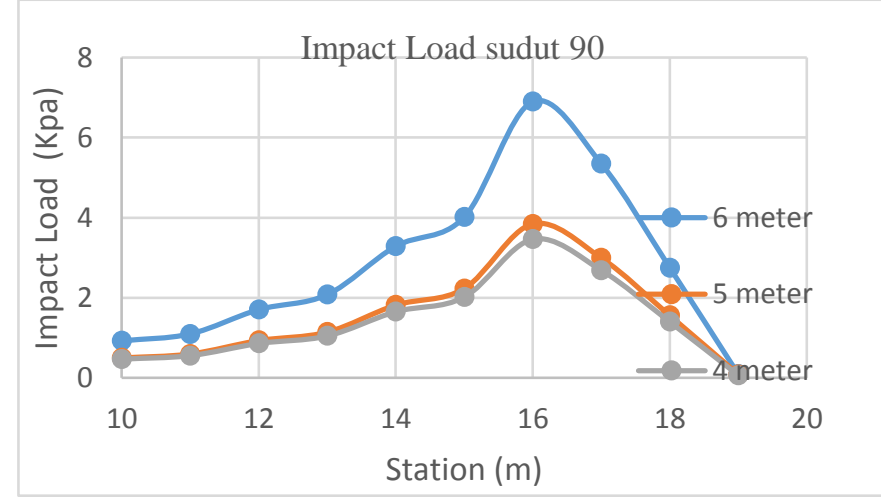

Gambar 7. Grafik impact load sudut $90^{\circ}$

Dari gambar 7 untuk sudut hadap $90^{\circ}$ beban slamming terbesar terdapat pada station 16 atau kisaran $0,15 \mathrm{~L}$ dari FP. 
Beban terbesar terjadi pada tinggi gelombang 6 meter dengan besar beban slamming sebesar $6.9 \mathrm{kPa}$.

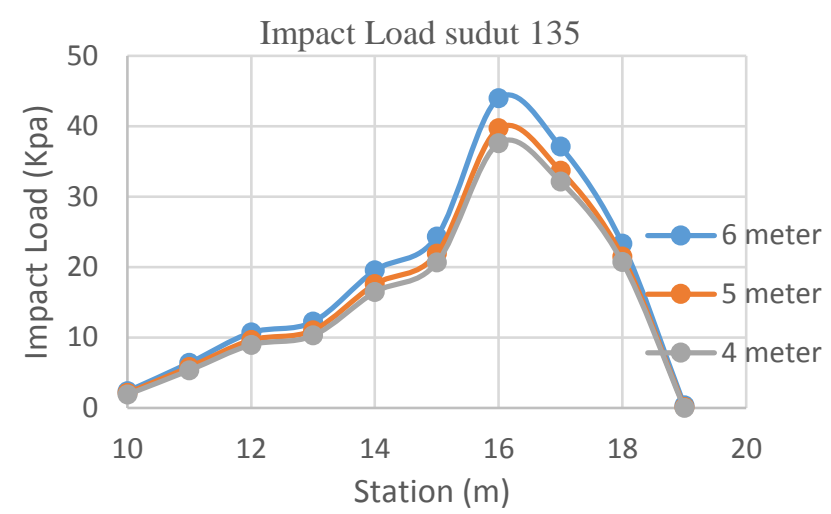

Gambar 8. Grafik impact load sudut $135^{\circ}$

Gambar 8 menunjukan bahwa beban slamming yang terjadi pada sudut $135^{\circ}$ terbesar pada tinggi gelombang 6 meter sebesar 43,99 kPa. Beban terbesar terletak di 0.15L dari FP.

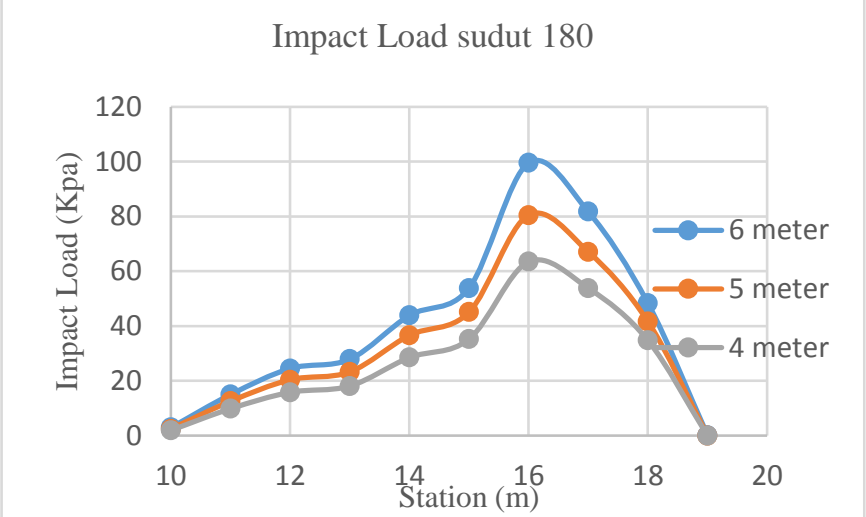

Gambar 9. Grafik impact load sudut $180^{\circ}$

Dari gambar 9 menunjukan beban slamming terbesar terjadi pada sudut hadap $180^{\circ}$ dengan tinggi gelombang 6 meter sebesar 92,619 kPa. Sehingga berdasarkan gambar 7, gambar 8, dan gambar 9 diatas disimpulkan bahwa beban terbesar akibat slamming terjadi pada sudut hadap $180^{\circ}$ dengan tinggi gelombang 6 meter. Sehingga dianjurkan apabila kapal berlayar menghindari kejadian tersebut.

2) Shear force dan Bending Moment

Analisa Selanjutnya adalah shear force dan bending moment. Beban slamming yang digunakan adalah penjumlahan antara shear force dan bending moment akibat beban gelombang dan shear force dan bending momen akibat beban slamming. Shear force dan bending moment terbesar akibat beban gelombang sebelum adanya slamming pada tinggi gelombang 6 meter sudut 180 pada st 16 adalah 47353 $\mathrm{kN}$ [7]. Setelah ditambah beban slamming besar shear force terbesar pada sudut 180 derajat pada tinggi gelombang 6 meter sebesar 272844 Kn.m dan bending moment terkecil pada sudut heading 90 derajat.

3) Hasil Simulasi

Dari hasil beban gelombang yang didapatkan dari analisa sehingga didapatkan besar tegangan sesuai pada tabel 4 dibawah.
Tabel 4.

Hasil simulasi

\begin{tabular}{|c|c|c|c|}
\hline \multirow{4}{*}{ Wave Height } & Heading & \multicolumn{2}{|c|}{ Stress } \\
\cline { 2 - 4 } & angle & $\sigma$ Bottom & $\sigma$ deck \\
\hline \multirow{3}{*}{ Hs =6m } & $\mu=90$ & 28.89 & 22.41 \\
\cline { 2 - 4 } & $\mu=135$ & 116.00 & 89.97 \\
\cline { 2 - 4 } & $\mu=180$ & 213.32 & 165.45 \\
\hline \multirow{3}{*}{ Hs =5m } & $\mu=90$ & 37.31 & 28.94 \\
\cline { 2 - 4 } & $\mu=135$ & 131.86 & 102.27 \\
\cline { 2 - 4 } & $\mu=180$ & 183.74 & 142.51 \\
\hline \multirow{3}{*}{$H s=4 \mathrm{~m}$} & $\mu=90$ & 23.65 & 30.49 \\
\cline { 2 - 4 } & $\mu=135$ & 96.33 & 124.20 \\
\cline { 2 - 4 } & $\mu=180$ & 116.62 & 150.35 \\
\hline
\end{tabular}

Dan tegangan terbesar terjadi gelombang 6 meter dengan sudut hadap $180^{\circ}$ mencapai $213,32 \mathrm{~N} / \mathrm{mm}^{2}$ pada bottom dan $165,45 \mathrm{~N} / \mathrm{mm}^{2}$ pada geladak. Dengan tegangan yang diijinkan oleh class adalah $243.4 \mathrm{~N} / \mathrm{mm}^{2}$

\section{V.KESIMPULAN DAN SARAN}

\section{A. Kesimpulan}

Kesimpulan yang didapat dari Tugas Akhir ini adalah sebagai berikut:

1) Probabilitas slamming paling besar terjadi pada sudut $180^{\circ}$ dengan panjang gelombang 6 meter dengan nilai probabilitas sebesar 0.71. Pada tinggi gelombang 4-6 meter pada sudut $180^{\circ}$ probabilitas terjadinya slamming memiliki kisaran 0.467 - 0.71. sedangkan pada sudut hadap $135^{\circ}$ memiliki kisaran probabilitas slamming sebesar 0.328 - 0.501 serta pada sudut hadap $90^{\circ}$ memiliki probabilitas sebesar $0.006-0.030$

2) Jumlah kejadian slamming paling besar terjadi pada gelombang dengan sudut hadap $180^{\circ}$ dengan tinggi gelombang 6 meter dengan nilai kejadian slamming per jam mencapai 528 kali kejadian. pada sudut hadap $135^{\circ}$ dengan tinggi gelombang 6 meter mencapai 342 kali kejadian per jam sedangkan untuk sudut hadap $90^{\circ}$ hanya terjadi 12 kali terjadi slamming.

3) Beban Slamming terbesar terjadi pada sudut hadap $180^{\circ}$ dengan tinggi gelombang 6 meter sebesar $92,619 \mathrm{kPa}$ di fr 142 disekitar $0.15 \mathrm{~L}$ dari FP. Pada sudut $135^{\circ}$ terbesar pada tinggi gelombang 6 meter sebesar 43,99 $\mathrm{kPa}$. Sedangkan pada sudut hadap $90^{\circ}$ pada gelombang 6 meter hanya sebesar $6.9 \mathrm{kPa}$. Sehingga dianjurkan apabila kapal berlayar menghindari kejadian sudut hadap $180^{\circ}$ pada tinggi gelombang 6 meter.

4) Nilai tegangan yang maksimal terjadi pada kondisi heading angle $180^{\circ}$ dengan tinggi gelombang 6 meter pada bagian battom mencapai 213,32 N/mm ${ }^{2}$ dan tegangan dideck sebesar 165,45 N/mm². Berdasarkan BKI Rules section 5 [8] bahwa tegangan ijin untuk material AH36 sebesar $243.4 \mathrm{~N} / \mathrm{mm}^{2}$. Sehingga dapat disimpulkan bahwa tegangan pada kapal perang akibat beban slamming masih memenuhi standart maksimum yang dijinkan class. 


\section{B. Saran}

Pada Tugas Akhir ini saran yang dapat diberikan adalah sebagi berikut:

1) Pada penelitian selanjutnya bisa dilakukan analisa fatigue life yang diakibatkan oleh beban slamming pada beberapa kondisi pelayaran Indonesia.

2) Penelitian selanjutnya bisa ditambahkan variasi kecepatan kapal dan variasi bentuk badan kapal.

3) Analisa local stress akibat slamming yang terjadi bisa digunakan dengan finite elemen method.

\section{DAFTAR PUSTAKA}

[1] E. B. Djatmiko, Perilaku dan Operabilitas Bangunan Laut di Atas Gelombang Acak, Surabaya: ITS Press, 2012.

[2] W. H. Nugroho and A. S. Mujahid, Head Sea Slamming Pressure Prediction on a Frigate Ship Hull (A Numerical Study).

[3] R. Bhattacharyya, Dynamics of Marine Vihicles, Marryland: U. S. Naval Academy, 1978.

[4] D. I. Perdana, "Analisa Beban Gelombang pada Konstruksi Kapal Perang Tipe Corvette di Kondisi Perairan Indonesia," Institut Tekonologi Sepuluh Nopember, Surabaya, 2013.

[5] J. R. McDermot, "WAMIT-MOSES Hydrodynamic Analysis Comparasion Study," Hull Department Engineering, 2000.

[6] G. Lloyd, Poseidon User Manual Guide, DNV GL, 2012.

[7] P. Y. Arifianto, "Analisa Tegangan Akibat Beban Gelombang pada Struktur Kapal Perang Tipe Corvette," Tugas Akhir: Jurusan Teknik Perkapalan Institut Teknologi Sepuluh Nopember, Surabaya, 2016.

[8] BKI, Rules for The Classification and Construction of Seagoing Stell Ships (VoL. II), Indonesia: BKI, 2009. 